\title{
ON THE POLITICAL POWER OF THE ACT OF 16 FEBRUARY 1918*
}

\section{CESLOVAS LAURINAVIČIUS}

\section{Lithuanian Institute of History, Vilnius}

This essay aims at discussing the genesis and development of Lithuania as an independent state not only on the basis of traditional historical scholarship, but also in its geopolitical and politological aspects. Such an attempt would not be original. In his day Stasys Salkauskis endeavoured to solve the problem of Lithuanian statehood. True, at that time the distance between the independence struggle and its recollection was merely two decades. Therefore, it seems meaningful to discuss the same issue again from the perspective of eight decades, assessing and weighing the political power of the Act of 16 February as a certain permanent value.

In principle, the idea of an independent ethnographic Lithuania presupposed the country as a buffer state between Russia, Poland and Germany. Indisputably, the main precondition of that variant was the modern Lithuanian national movement and its geopolitical orientation, discernible since the second half of the nineteenth century, more precisely since the appearance of the Aušra (Dawn) newspaper. That orientation meant the rejection of the union with Poland and the renunciation of the former Russian territories of the Grand Duchy of Lithuania (henceforth GDL) in the east, i.e., Belorussia. It could be surmised that that sort of attitude was expected to weaken the pressure of Russia in respect to ethnographic Lithuania and to create a counterbalance to the spread of Polonization.

It is understandable that that sort of compromise with Russia was also typical of other modern nations on the western outskirts of the empire. In general, it could be said that modern national movements on the fringes of Russia implied not only common democrat-

*Both reports of this Section were delivered at the conference 'The Lithuanian Independence Declaration of 16 February 1918 in the East European Context', held at the Lithuanian Institute of History on 12-13 February 1998. 
ization processes, but also expedient deals of one oppressed party with the oppressor against the other. Taken all in all, that meant a certain geopolitical westward movement without any clearer limit. In the end that trend led to a global military confrontation between Russia and the German empire. The war, in its turn, opened the perspective of independence for the subjugated nations. That perspective was based largely on the spread of democratic ideas. However, since the relationship of the movements of those nations with democracy was controversial, the war did not eliminate a new 'Holy Alliance', i.e., the chances of a new compromise between Russia and Germany. Namely in this compromise, the signs of which were visible already in 1915, there appeared the crystallization of the Lithuanian issue. And in 1917 the main parameters of that issue became quite evident.

Having occupied the whole of ethnographic Poland and Lithuania, Germany was faced with a dilemna of either letting renascent Poland develop eastwards and thus losing the chance of effective entrenchment in Lithuania and possibly being deprived of the ties with Russia or opposing the development of Poland by supporting Lithuania with Vilnius, thus taking upon itself a burden of the Polish-Lithuanian quarrel.

In principle, Russia, too, was not disposed to reconcile with Poland's development in the former territories of the GDL, therefore there appeared a common German-Russian interest to keep Lithuania as a balance to Poland.

For Lithuania, more precisely for the Lithuanians, that situation also presented a dilemma: either to strengthen anti-Polish attitudes thus creating a precondition for Germany (and eventually for Russia) to dominate in the country, or to evade such a situation by passing over from the confrontation to the search of civil consolidation with Lithuanian Poles.

The Act of 16 February 1918, proclaiming the independence of Lithuania in its ethnic territory and requiring the approval of that document by the Constituent Seimas, elected by all inhabitants, not only formally fixed the geopolitically conditioned aims of the Lithuanian state, but also entailed the utmost effort to win popular consent for that projected state. Thus, the Act of 16 February in actual fact supposed independent Lithuania among Russia, Germany and Poland.

However, in the concrete situation of the time this Act was closely associated with one more act of the Lithuanian Council, adopted on 11 December 1917, creating conditions for Germany to annex Lithuania. Such a possibility was attested by subtle diplomatic 
steps on the side of both the Lithuanian Council (Taryba) and of Germany. Some German politicians believed that even after a freewill endorsement of the Act of 16 February of the Constituent Seimas the Lithuanians would not dare to stop placing reliance on Germany, and that, in the opinion of the world, would be more acceptable than outright annexation. However, in Lithuania at that time there was no guarantee and respectively no elimination of the conditions for Germany's establishment in the country. The dominating tendency of Lithuanian diplomacy was the belief that the ties with Germany were inevitable, no matter how dangerous they could be, and the Act of 16 February was intended to suppress German ambitions. One could only guess that if all the Great Powers had participated at the Peace conference, the Lithuanian issue would have been dealt with between 11 December and 16 February.

However, after the First World War Germany and Russia lost their military supremacy. The forces preventing Poland's expansion into Lithuania were weakened to a great extent, though they did not disappear altogether. On the other hand, the influence of the Allies grew, but, although it was significant, it was not effective enough, as it was based on certain geopolitical concepts rather than on direct intervention. According to one of them, the British buffer concept, attempts were made to create a buffer of Eastern European states, including Lithuania. That buffer was intended to return Russia (eventually even the Bolshevik one) and Germany to international concord as soon as possible. According to the French barrier concept, the interests of the legitimate Russian state had to be conserved, while the Eastern Baltic states (with Poland in the first place) had to exert permanent pressure both on the Bolsheviks and on Germany. The Supreme Council of the Allies made an agreement only in respect to the conservation of the rights of Russia. That was attested by the demarcation lines drawn up by the Council in 1919. They resembled a sort of sluice, blocking or facilitating one or another movement, depending on its direction and level. For example, on 26 July 1919 Poland was given the right to drive out the Bolsheviks from Eastern Lithuania according to the socalled Foch line. However, according to the line of 8 December (in the same year) the development of Poland in Lithuania was already treated only as temporary. Still further, the Spa Conference decisions of 9 July 1920 showed that Lithuania was conceived of as an independent buffer among Germany, Poland and Russia. Poland had to withdraw its troops behind the line of 8 December and to transfer Vilnius and its territory to Lithuania. Such castling had to abolish the motive of the Bolshevik westward movement and create preconditions for the conference in London, at which Lithuanian statehood could have been constitutionalized by the prestige of the Great Powers. 
That project failed largely due to the position of the Lithuanians, who gave up the Spa decision and preferred the formula 'The Red Army cannot stop' and agreed to the occupation of Vilnius by that army. Comparing the conceptual analogies of 11 December and 16 February, the Lithuanians chose the first variant, i.e., they let Soviet Russia have Lithuania in the hope that the Soviets would break Polish domination in Eastern Lithuania and afterwards the Soviets themselves would be ousted on the basis of their own recognition of Lithuanian independence. However, that sort of diplomacy did not aid the formation of civil society in Lithuania and removed the nation from the ideals of 16 February. On the other hand, it contradicted the intentions of the Allies - the concept of the buffer, still less that of the barrier. Exploiting the situation, Poland occupied Vilnius and cut Lithuania off from Bolshevik Russia.

As events turned out, the independent Lithuanian state survived, but it was not stable both internally and externally. Lithuanian politicians associated the main threat with Poland's destruction of the equilibrium of forces, geopolitically indispensible for Lithuania. Germany and Russia, in principle dissatisfied with the Polish barrier, also urged Lithuania to stick to that sort of attitude. Thus, in Lithuania there developed a total orientation that the Polish barrier should be removed. The symbol of that orientation was the mission of the liberation of Vilnius, sharply engraved on Lithuanian consciousness; and it became the principal condition of national identification. Thus it would seem that powerful forces were concentrated for the reconstruction of the geopolitical space, foreseen by the Act of 16 February. An unbiased observer, however, could easily see that the creation of the Lithuanian independent state in that sphere was no more attainable, because the sanction of the Constituent Seimas, inherent in that independence was no longer feasible. True, there remained the variant of 11 December; however, in the interwar situation it soon became clear that that variant did not any more offer a chance of diplomatic balancing as in 1918, but an uncontrollable outbreak of Pan-Germanism or Pan-Slavism.

When, at the beginning of October 1939, the Soviets began to blackmail the Lithuanian government requiring permission to establish military bases for the Red Army in Lithuania and offering Vilnius in exchange, the Lithuanian government could not consider resistance, because such a step most probably would not have been understood unequivocally. The geopolitical image, instilled in the nation, became politically ungovernable. After the stationing of Soviet troops in the country, any safeguard for independence disappeared and soon Lithuania became a mere administrative unit in a vast 
empire, as it was approximately imagined on 11 December 1917 by the most radical Pan-Germanists.

The independent Lithuanian state could be re-established again only when the whole world understood that democracy was functioning normally in Lithuania. Therefore, at present it can be stated that the idea of the Act of 16 February 1918 has been realized and that the eight-decade-long way (1918-1998) of the Lithuanian nation means the way to the ideals the Act.

Conclusions

We may say that historical perspective that we have today permits certain conclusions. The specificity of Lithuanian statehood in modern times lies in the fact that its conditions were created by unique geopolitical factors. However, the Lithuanian example is also an indication that those factors, no matter how powerful they might be, at the same time can play an indeterminate role, resembling a phantom, if there is no civil society to cement the statehood preconditions. Comparing geopolitical and social factors, priority should be given to the latter. Lithuanian experience shows that the geopolitical space can make a small nation its own pawn and a subject of the intrigue of Great Powers; it can divide the nation and encourage adventurism and demagoguery and demoralize it for a long time. Taking into account that experience, it is much more preferable to envisage Lithuania as a constituent part of the democratic world rather than a buffer state between Great Powers. 